\title{
Characterization of Bioactive Compounds in Colored Potato (Solanum Tuberosum L.) Cultivars Grown with Conventional, Organic, and Biodynamic Methods
}

 \\ Honorata Danillčenko ${ }^{1}$, Dominika Średnicka-Tober ${ }^{2}$ (1), Ewa Rembiałkowska ${ }^{2}$ (I) \\ and Ewelina Hallmann ${ }^{2}$ \\ 1 Institute of Agriculture and Food Sciences, Agriculture Academy, Vytautas Magnus University, \\ Donelaičio str. 58, 44248 Kaunas, Lithuania; jurgita.kulaitiene@vdu.lt (J.K.); elvyra.jariene@vdu.lt (E.J.); \\ dovile.levickiene@vdu.lt (D.L.); honorata.danilcenko@vdu.lt (H.D.) \\ 2 Department of Functional and Organic Food, Institute of Human Nutrition Sciences, \\ Warsaw University of Life Sciences, Nowoursynowska 159c, 02-776 Warsaw, Poland; \\ dominika_srednicka_tober@sggw.pl (D.Ś.-T.); ewa_rembialkowska@sggw.pl (E.R.); \\ ewelina_hallmann@sggw.pl (E.H.) \\ * Correspondence: nijole.vaitkeviciene@vdu.lt; Tel.: +370-37-752-326
}

Received: 24 January 2020; Accepted: 26 March 2020; Published: 30 March 2020

\begin{abstract}
The purpose of this research is to evaluate the effect of conventional, biodynamic, and organic cultivation methods on the contents of polyphenols and carotenoids in tubers of potato cultivars with different colored flesh: "Red Emmalie", "Salad Blue", "Violetta", "Tornado", and "Laura". These bioactive compounds were determined by the high-performance liquid chromatography method. The data received were analyzed with ANOVA and further explored and visualized by principal component analysis. Higher contents of polyphenols (sum), phenolic acids (sum), chlorogenic acid, $p$-coumaric acid, and caffeic acid were found in biodynamic and organic samples compared to the conventional tubers. Moreover, organically and biodynamically produced potatoes (except "Salad Blue" cultivar) were significantly richer in flavonoids and anthocyanins. The highest contents of carotenoids (sum), lutein, and $\beta$-carotene were found in biodynamic potatoes. Among the tested cultivars, "Tornado", with white flesh, was richest in polyphenols (sum), phenolic acids (sum), chlorogenic acid, and p-coumaric acid. "Violetta", with dark purple flesh, accumulated the highest contents of flavonoids (sum), anthocyanins (sum), petunidin-3,5-di-O-glucoside, pelargonidin-3,5-di-O-glucoside, and peonidin-3,5-di-O-glucoside. Carotenoids were only found in "Laura" tubers, and the dominating carotenoid was lutein.
\end{abstract}

Keywords: potato; phenolic compounds; carotenoids; anthocyanins; conventional; organic; biodynamic

\section{Introduction}

Consumers are increasingly focusing not only on the quality of raw materials but also on the sustainability of food. According to the statistics, potatoes are one of the most popular and most consumed food products in the world [1]. Their nutritional value is high as they are a rich source of carbohydrates, high-quality proteins, macro- and microelements, and vitamins. [2]. Lately, colored potatoes have attracted the attention of scientists and consumers, for their sensual attraction, nutritional value, and antioxidant activities. These potatoes are rich in polyphenols, anthocyanins, flavonoids, carotenoids, tocopherols, and vitamin C [3,4].

The literature data show that polyphenols and other antioxidants may prevent cancers, cardiovascular disease, and a number of other noncommunicable diseases. Reddivari et al. [5] have 
shown in their in vitro experiment that bioactive compounds of potatoes-anthocyanins and phenolic acids-suppressed the proliferation of human melanoma and glioblastoma cells. There are some data that the phytochemicals of freeze-dried potato powder caused a $23 \%$ reduction in the risk of cancer in rats [6]. Nichenametla et al. [7] indicated that chlorogenic and ferulic acid decreased lung tumors in rats by $30 \%-40 \%$. The anthocyanins and their aglycones present in red- and purple-fleshed potatoes have been found to exert proapoptotic and antiproliferative properties in gastric adenocarcinoma, colon cancer, and bovine aortic endothelial cells $[8,9]$.

The growing concern about the spread of chemical inputs in the agro-environment, as well as their economic and social impacts, has prompted many farmers and consumers to look for alternative methods and systems in order to make agriculture more sustainable. According to the literature, organic and biodynamic farming systems are recognized as environmentally friendly technologies. According to researchers, this type of farming can have a positive impact on soil biodiversity and biological activity, and the harvested products characterized by a higher nutritional value $[10,11]$.

Biodynamic practice is a unique system of organic farming, which contributes not only to the development of sustainable farming but also to solving environmental issues [10]. The main difference between organic and biodynamic growing systems is that biodynamic farmers use special preparations to stimulate and regulate processes of nutrient and energy cycling and to improve soil and crop quality [12].

According to the carbon-nutrient balance hypothesis, if nitrogen is easily accessible in the soil, plants have a tendency to grow quicker but to produce less bioactive compounds, such as polyphenols. When nitrogen availability is limited, the relative surplus of assimilates may change into compounds that contain carbon (polyphenols) [13]. It is also well-known that stress during the vegetative stage is directly related to the response of the plants, manifested in the formation of large numbers of specialized compounds of secondary metabolism (e.g., polyphenols) [14]. Moreover, the total amount, range, and proportions of individual phenolic compounds could be affected by the genetic variation (cultivars), climatic conditions, storage conditions after harvest, and many other factors [15-17].

Several studies concluded that potatoes cultivated according to organic or biodynamic growing recommendations have a higher content of bioactive compounds compared to conventional crops [18-22]. Nevertheless, the availability of comprehensive research targeting this subject is very limited. It remains necessary to compare different farming systems and to evaluate the potential benefits of biodynamic farming. Our previous research showed that biodynamic preparations promoted the activity of soil enzymes and the accumulation of some bioactive compounds in the potato tubers with a colored flesh $[4,23]$. However, the application of this system, as well as a comparison of its efficiency with other systems, has not yet been comprehensively investigated and applied by farmers. In addition, no attempts have been focused on the effects of different farming systems on the accumulations on bioactive compounds in colored potatoes. The aim of this study is, therefore, to examine the influence of the farming system (organic, biodynamic, conventional) on the accumulation of bioactive compounds in the tubers of selected potato cultivars with different colored flesh.

\section{Materials and Methods}

\subsection{Chemicals}

The following chemicals were used in the procedures that follow: acetonitrile of HPLC purity (Sigma-Aldrich, Poland), deionized water (Sigma-Aldrich, Poland), ethyl acetate of HPLC purity, (Merck, Poland), methanol of HPLC purity (Merck, Poland), ortho-phosphoric acid 99.9\% (Chempur, Poland), hydrochloric acid 36\% (Chempur, Poland), phenolics standards (purity 99.5\%-99.9\%): gallic acid, chlorogenic acid, caffeic acid, $p$-coumaric acid, quercetin-3-O-rutinoside, quercetin-3-O-glucoside, quercetin, pelargonidin-3,5-di-O-glucoside, peonidin-3,5-di-O-glucoside, petunin-3,5-di-O-glucoside (Sigma-Aldrich, Poland), lutein, zeaxanthin, $\beta$-carotene (Sigma-Aldrich, Poland). 


\subsection{Plant Material}

Five potato cultivars were selected for the study (Table 1). The experiment was conducted in 2017-2018 at a farm located in Širvintos district (latitude, $54^{\circ} 54^{\prime} 43^{\prime} \mathrm{N}$; longitude, $25^{\circ} 06^{\prime} 07^{\prime} \mathrm{E}$ ), Lithuania.

Table 1. A description of potato cultivars.

\begin{tabular}{lccccc}
\hline \multirow{2}{*}{ Characteristics } & \multicolumn{4}{c}{ Cultivar } \\
\cline { 2 - 6 } & "Red Emmalie" & “Violetta" & “Salad Blue" & "Laura" & "Tornado" \\
\hline Maturity time & Medium early & Early & Early & Medium early & Early \\
Flesh color & Red & Dark purple & Light blue-purple & Yellow & White \\
Skin color & Red & Dark purple & Dark blue-purple & Red & Red \\
Tuber shape & Long & Long & Short, oval & Long oval & Oval \\
Cooking type & $\mathrm{B}^{1}$ & $\mathrm{~B}$ & $\mathrm{BC}^{2}$ & $\mathrm{BC}$ & BC \\
\hline
\end{tabular}

${ }^{1}$ Cooking type B: Potatoes slightly floury, disintegrating and with rather fine-textured flesh (European Association for Potato Research cooking type scale); ${ }^{2}$ Cooking type C: Potatoes dry, with floury flesh, coarse, and a rather marked disintegration (European Association for Potato Research cooking type scale).

Potatoes were planted by applying traditional technology in three different growing systems: conventional, organic, and biodynamic. The field was deeply plowed in autumn, cultivated twice in spring, and furrowed before potato planting. The potatoes were planted at the 3 rd ten-day period of April and harvested at maturity at the 1st ten-day period of September. The distance between the rows was $70 \mathrm{~cm}$, the distance between tubers was $30 \mathrm{~cm}$, and the depth was about $7 \mathrm{~cm}$.

In each farming system, the experiment was laid out in a randomized design and was performed in four replications. The total plot area was $50 \mathrm{~m}^{2}(8 \times 6.25 \mathrm{~m})$, the size of the accounting plot $-32 \mathrm{~m}^{2}$ $(6.60 \times 4.85 \mathrm{~m})$, and the width of the protection belt $-0.7 \mathrm{~m}$.

Soil samples for the determination of the general agrochemical characteristics were taken before the establishment of the trial from all farming system fields. In each replication of the treatment, composite soil samples were taken from 5 places from the arable layer $(0-20 \mathrm{~cm}$ depth) using a soil auger. The samples were air-dried, crushed in a porcelain mortar, sieved using a 2-mm sieve, and analyzed.

In the conventional agricultural field, the mix of universal complex fertilizers (N:P:K 14:7:17) was used at planting by inserting $112 \mathrm{~kg} \mathrm{ha}^{-1}$ of nitrogen, $56 \mathrm{~kg} \mathrm{ha}^{-1}$ of phosphorus, and $136 \mathrm{~kg} \mathrm{ha}^{-1}$ of potassium. For crop protection, herbicide (Nufarm MCPA $2.31 \mathrm{ha}^{-1}$, active substance MCPA $750 \mathrm{~g} \mathrm{l}^{1}$ ) was used in the field before potato germination. Moreover, fungicides Infinito (1.6 $1 \mathrm{ha}^{-1}$, active substances propamocarb hydrochloride $625 \mathrm{~g} \mathrm{l}^{-1}$ and fluopicolide $62.5 \mathrm{~g} \mathrm{l}^{-1}$ ) and Gloria (2 $1 \mathrm{ha}^{-1}$, active substances fenamidone $75 \mathrm{~g} \mathrm{l}^{-1}$ and propamocarb hydrochloride $375 \mathrm{~g} \mathrm{l}^{-1}$ ), in combination with insecticide Mavrik Vita $\left(0.21 \mathrm{ha}^{-1}\right.$, active substance tau-fluvalinate $\left.240 \mathrm{~g} \mathrm{l}^{-1}\right)$, were applied at the inflorescence formation and two flowering periods. The soil in the conventional field was characterized by $\mathrm{pH}_{\mathrm{KCl}} 5.37-5.41$, available $\mathrm{K}_{2} \mathrm{O} 267-279 \mathrm{mg} \mathrm{kg}^{-1}$, available $\mathrm{P}_{2} \mathrm{O}_{5} 140-142 \mathrm{mg} \mathrm{kg}^{-1}$, mineral nitrogen $44.25-47.71 \mathrm{mg} \mathrm{kg}^{-1}$, and humus $2.11 \%-2.32 \%$.

In the biodynamic and organic agricultural fields, potatoes were grown in accordance with the Demeter Biodynamic and International Federation of Organic Agriculture Movements standards, which promote ecologically sustainable farming practices and prohibit synthetic pesticides, synthetic fertilizers, genetically engineered seeds, artificial ingredients, and other inputs that can be used in conventional agriculture and food processing.

Organic fields using those methods have been managed 15 years, with a 2-year transition to biodynamic farming, and biodynamic fields have been managed for 3 years using those methods. Potatoes were grown after the oats (Avena sativa), and the oats were grown after the clover (Trifolium). Prior to planting the potato seed tubers were not treated with any chemicals.

In the organic field, in spring, before the first cultivation, the soil was fertilized with $30 \mathrm{t} \mathrm{ha}^{-1}$ of compost (compost composition: $\mathrm{pH}_{\mathrm{KCl}} 6.97$, available $\mathrm{P}_{2} \mathrm{O}_{5} 1932.49 \mathrm{mg} \mathrm{kg}^{-1}$, and mineral nitrogen 
$52.73 \mathrm{mg} \mathrm{kg}^{-1}$ ). The soil properties were as follows: $\mathrm{pH}_{\mathrm{KCl}} 5.36-5.42$, available $\mathrm{K}_{2} \mathrm{O} 186-192 \mathrm{mg} \mathrm{kg}^{-1}$, available $\mathrm{P}_{2} \mathrm{O}_{5} 172-174 \mathrm{mg} \mathrm{kg}^{-1}$, mineral nitrogen $36.03-43.23 \mathrm{mg} \mathrm{kg}^{-1}$, and humus $2.07 \%-2.30 \%$.

In the biodynamic system, the potato crops were fertilized with biodynamic compost $\left(30 \mathrm{t} \mathrm{ha}^{-1}\right)$. The compost composition was as follows: $\mathrm{pH}_{\mathrm{KCl}} 6.83$, available $\mathrm{P}_{2} \mathrm{O}_{5} 159.108 \mathrm{mg} \mathrm{kg}^{-1}$, and mineral nitrogen $51.09 \mathrm{mg} \mathrm{kg}^{-1}$. Compost also was added in spring before the first cultivation. In the biodynamic field, the main soil properties were as follows: $\mathrm{pH}_{\mathrm{KCl}} 5.77-5.81$, available $\mathrm{K}_{2} \mathrm{O} 179-182 \mathrm{mg}$ $\mathrm{kg}^{-1}$, available $\mathrm{P}_{2} \mathrm{O}_{5} 174-184 \mathrm{mg} \mathrm{kg}^{-1}$, mineral nitrogen $41.62-45.71 \mathrm{mg} \mathrm{kg}^{-1}$, and humus $1.71 \%-1.86 \%$. The field was sprayed with biodynamic (BD) preparation 500 two weeks prior to the potato planting, with $1 \%$ solution $\left(2001 \mathrm{ha}^{-1}\right)$, and with BD preparation 501 twice-at the bud formation period (BBCH $59)$ and at the flowering period (BBCH 65-70), with $0.5 \%$ solution $\left(2001 \mathrm{ha}^{-1}\right)$. BD preparation 500 is fermented manure with the following composition: plant-available phosphorus $\left(\mathrm{P}_{2} \mathrm{O}_{5}\right)-1668 \mathrm{mg} \mathrm{kg}^{-1}$; plant-available potassium $\left(\mathrm{K}_{2} \mathrm{O}\right)-291 \mathrm{mg} \mathrm{kg}^{-1}$; total nitrogen-2.28\%, $\mathrm{pHKCl}-6.86$; urease enzyme activity-1.64 $\mathrm{mg} \mathrm{NH}_{3} 1 \mathrm{~g}^{-1}$ soil per $24 \mathrm{~h}$; saccharase enzyme activity-31.8 $\mathrm{mg}$ glucose $1 \mathrm{~g}^{-1}$ soil per 48 h. BD preparation 501 is a quartz crystal rock $\left(\mathrm{SiO}_{2}-99.8 \%\right)$, ground very finely. The soil, as well as the potato plants, were sprayed with tested preparations according to the methods and rules set out for European biodynamic farms.

The biodynamic preparations 500 and 501, as well as organic and biodynamic composts, were obtained from the Demeter-certified farm in Lithuania. In both organic and biodynamic farming systems, weeds are managed by mechanical measures. Colorado potato beetles (Leptinotarsa decemlineata) and their larvae are removed by hand.

\subsection{Sample Preparation}

In the course of the experiment, twenty tubers were randomly sampled from each treatment. Tubers were washed, dried, cut into slices (approximately $10 \mathrm{~mm}$ ), and immediately frozen at $-35^{\circ} \mathrm{C}$. The samples were then lyophilized with a Sublimator (ZIRBUS Technology GmbH, Germany), powdered with a knife mill (Grindomix GM 200, Germany), and stored in airtight plastic bags in the refrigerator.

\subsection{Polyphenols Extraction and Identification}

Phenolic compounds concentrations were measured by high-performance liquid chromatography (HPLC) method described previously in details by Kazimierczak et al. [18]. In brief: $0.100 \mathrm{mg}$ of freeze-dried potato sample was extracted with methanol and deionized pure water $(5 \mathrm{~mL}, 80: 20 \mathrm{v} / \mathrm{v})$. In the next step, the samples were mixed on Vortex (Cole-Parmer, Germany) and extracted in an ultra-sonic cold water bath $\left(0{ }^{\circ} \mathrm{C}, 10 \mathrm{~min}, 5.5 \mathrm{kHz}\right)$. After extraction, samples were centrifuged (6000 rpm, $10 \mathrm{~min}$, temperature $0{ }^{\circ} \mathrm{C}$ ). Then, $900 \mu \mathrm{L}$ of supernatant was injected into HPLC-vial, and $100 \mu \mathrm{L}$ was injected into the HPLC column (Phenomenex, Fusion-80A, C-18, practical shape $4 \mu \mathrm{m}$, $4.6 \times 250 \mathrm{~mm}$, Shim-Pol, Poland). Phenolic compounds were identified according to the standards (Figures S1 and S2 Supplementary Materials), and their retention times. The wavelengths used were as follows: $250 \mathrm{~nm}$ for phenolic acids (gallic, chlorogenic, caffeic, $p$-coumaric), $370 \mathrm{~nm}$ for flavonoids (quercetin-3-O-rutinoside, quercetin-3-O-glucoside, quercetin). Time of analysis: $38 \mathrm{~min}$. The results were expressed in $\mathrm{mg} 100 \mathrm{~g}^{-1} \mathrm{FM}$.

\subsection{Anthocyanins Extraction and Identification}

Anthocyanins were measured by the HPLC method according to the protocol previously described by Rodriguez-Saona et al. [17]; in brief, supernatant from phenolic compounds analysis was mixed with $10 \mathrm{M} \mathrm{HCl}$ (hydrochloric acid; $2.5 \mathrm{~mL}$ ), and pure $100 \%$ methanol $(5 \mathrm{~mL})$. Samples were extracted in cold place $\left(5{ }^{\circ} \mathrm{C}\right.$, time $\left.10 \mathrm{~min}\right)$ and softly mixed. Then, $1 \mathrm{~mL}$ of extract was transferred to HPLC-vial and $100 \mu \mathrm{L}$ was injected into an analytical column. The analysis was carried out with a wavelength of $530 \mathrm{~nm}$, and the time of the analysis was $18 \mathrm{~min}$. Anthocyanins (pelargonidin-3,5-di-O-glucoside, peonidin-3,5-di-O-glucoside, petunin-3,5-di-O-glucoside) were identified based on their pure chemical 
standards and retention time (see chromatograms in Figures S1 and S2 and Figures S3-S5 in the Supplementary Materials).

\subsection{Carotenoids Extraction and Identification}

Carotenoid compounds were quantified by the high-performance liquid chromatography (HPLC) method described by Hallmann [24], with some modifications. Briefly, $0.100 \mathrm{mg}$ of lyophilized sample was extracted with acetone $(5 \mathrm{~mL})$ using an ultrasonic bath for 10 minutes at $0{ }^{\circ} \mathrm{C}$. Then, samples were centrifuged for 10 minutes $\left(6000 \mathrm{rpm}, 0^{\circ} \mathrm{C}\right)$. Next, $1 \mathrm{~mL}$ of supernatant was transferred into an HPLC vial. The wavelength used for detection was $445-450 \mathrm{~nm}$. The time of analysis was set at $28 \mathrm{~min}$. The content of carotenoids in the potato samples was calculated using a standard curve (Figures S1 and S2 Supplementary Materials) and considering the dilution coefficient, and was expressed in $\mathrm{mg}$ $100 \mathrm{~g}^{-1}$ fresh mass (FM).

\subsection{Statistical Analysis}

The data on the bioactive compounds of potato tubers were processed with Microsoft $(E x c e l \circledast 2016$ MSO software and STATISTICA 10 (Statistica 10; StatSoft, USA) package. The effects of the production system and the cultivar on the chemical composition of tubers were evaluated by ANOVA, followed by the post-hoc Tukey's HSD test $(p<0.05)$. Principal component analysis was performed with the XLSTAT Software package (XLSTAT, 2018, USA) in order to explore the variation and identify potential patterns within the dataset.

\section{Results and Discussion}

\subsection{Polyphenols Content}

In the present study, biodynamically produced tubers contained higher contents of phenolics (sum) and phenolic acids (sum) (on average 127.54 and $104.05 \mathrm{mg} 100 \mathrm{~g}^{-1} \mathrm{FM}$, respectively) compared


(on average 97.16 and $74.21 \mathrm{mg} 100 \mathrm{~g}^{-1} \mathrm{FM}$, respectively) farming systems (Table 2). However, significant differences were only identified between the samples from conventional and biodynamic farming systems. When looking into the individual potato cultivars, most of them, when grown organically (except for "Salad Blue" and "Tornado") and biodynamically (except for "Salad Blue"), accumulated more phenolic compounds than those that were conventionally grown. As reported by other authors, any significant stress factor in the agricultural environment impacts the plant metabolism, and also plant phenolics generation and transformations. Stress factors can be avoided or caused by different cultivation and fertilization methods. It is known that high nitrogen doses, while enhancing plant growth, can at the same time reduce the content of phenolic compounds in the plant, limiting its resistance to pests and diseases. At the same time, a limited supply of plant nutrients in the cultivation may increase the accumulation of secondary metabolites in plant tissues. The reason for this could be that primary growth is suppressed by a nitrogen deficiency, and the carbon is allocated to the secondary metabolism, including biological active compounds generation $[25,26]$.

As a result of qualitative analysis, four phenolic acids (gallic, chlorogenic, caffeic, and p-coumaric acids) were found in potato tubers. Chlorogenic acid was the predominant phenolic acid in all the tested cultivars, ranging from $94.61 \%$ to $98.19 \%$ of the total phenolic acid content (Table 2). The agricultural system was found to have a significant impact on the content of chlorogenic and p-coumaric acid in the tubers. Higher contents of these acids were found in biodynamic and organic tubers compared to the ones grown with conventional techniques. In agreement with our results, other researchers have found that potato tubers had significantly higher contents of polyphenols (sum), phenolic acids (sum), and most of the individual phenolic acids when grown in the organic system compared to the conventional system [18,27]. However, in the study of Brazinskiene et al. [28], the farming system had no significant effect on phenolic acid concentrations in the tubers. These authors reported that the 
phenolic acids content in potato tubers significantly depends on the genetic variation (cultivar) and the year-to-year differences in the growing conditions.

Table 2. The influence of the farming system on the contents of phenolics (sum) and phenolic acids in the tubers of 5 potato cultivars.

\begin{tabular}{|c|c|c|c|c|c|c|}
\hline \multirow{2}{*}{$\begin{array}{l}\text { Potato } \\
\text { Cultivars }\end{array}$} & $\begin{array}{l}\text { Phenolics } \\
\text { (sum) }\end{array}$ & $\begin{array}{c}\text { Phenolic } \\
\text { Acids (sum) }\end{array}$ & $\begin{array}{c}\text { Chlorogenic } \\
\text { Acid }\end{array}$ & $\begin{array}{l}\text { Gallic } \\
\text { Acid }\end{array}$ & $\begin{array}{c}p \text {-Coumaric } \\
\text { Acid }\end{array}$ & $\begin{array}{c}\text { Caffeic } \\
\text { Acid }\end{array}$ \\
\hline & \multicolumn{6}{|c|}{ mg $100 \mathrm{~g}^{-1}$ Fresh Mass (FM) } \\
\hline & \multicolumn{6}{|c|}{ Conventional Farming System } \\
\hline “Red Emmalie" & $55.19 \mathrm{H}^{1}$ & $36.91 \mathrm{G}$ & $35.53 \mathrm{~F}$ & $0.78 \mathrm{~F}$ & $0.44 \mathrm{~J}$ & $0.18 \mathrm{G}$ \\
\hline "Violetta" & $94.15 \mathrm{G}$ & $44.45 \mathrm{G}$ & $42.37 \mathrm{~F}$ & $1.31 \mathrm{CD}$ & $0.49 \mathrm{H}$ & $0.27 \mathrm{G}$ \\
\hline "Salad Blue" & 101.26 EFG & $65.76 \mathrm{EF}$ & $64.17 \mathrm{E}$ & $0.95 \mathrm{EF}$ & $0.47 \mathrm{I}$ & $0.19 \mathrm{G}$ \\
\hline “Tornado” & $146.47 \mathrm{~B}$ & $139.96 \mathrm{~B}$ & $135.78 \mathrm{~B}$ & $1.68 \mathrm{AB}$ & $0.66 \mathrm{DE}$ & $1.86 \mathrm{~B}$ \\
\hline “Laura” & $88.72 \mathrm{G}$ & 83.46 DE & $79.72 \mathrm{DE}$ & $1.94 \mathrm{~A}$ & $0.56 \mathrm{G}$ & $1.24 \mathrm{C}$ \\
\hline \multirow[t]{2}{*}{ Means } & $97.16 \mathrm{~B}$ & $74.21 \mathrm{~B}$ & $71.51 \mathrm{~B}$ & $1.33 \mathrm{~B}$ & $0.52 \mathrm{C}$ & $0.75 \mathrm{~A}$ \\
\hline & \multicolumn{6}{|c|}{ Organic Farming System } \\
\hline "Red Emmalie" & $92.01 \mathrm{G}$ & $64.31 \mathrm{~F}$ & $62.47 \mathrm{E}$ & $0.66 \mathrm{~F}$ & $0.57 \mathrm{G}$ & $0.61 \mathrm{~F}$ \\
\hline "Violetta" & $126.64 \mathrm{CD}$ & $66.25 \mathrm{EF}$ & $63.94 \mathrm{E}$ & $1.17 \mathrm{DE}$ & $0.44 \mathrm{IJ}$ & $0.70 \mathrm{EF}$ \\
\hline "Salad Blue" & $94.28 \mathrm{G}$ & $75.75 \mathrm{EF}$ & $71.67 \mathrm{E}$ & $1.34 \mathrm{BCD}$ & $0.64 \mathrm{EF}$ & $2.10 \mathrm{~A}$ \\
\hline “Tornado" & 116.03 DEF & $107.98 \mathrm{C}$ & $105.47 \mathrm{C}$ & $0.92 \mathrm{EF}$ & $0.61 \mathrm{~F}$ & $0.98 \mathrm{D}$ \\
\hline “Laura” & $136.96 \mathrm{BC}$ & $128.85 \mathrm{~B}$ & $125.79 \mathrm{~B}$ & $1.41 \mathrm{BCD}$ & $0.76 \mathrm{~B}$ & $0.89 \mathrm{DE}$ \\
\hline \multirow[t]{2}{*}{ Means } & $113.18 \mathrm{AB}$ & $88.63 \mathrm{AB}$ & $85.67 \mathrm{AB}$ & $1.10 \mathrm{~A}$ & $0.60 \mathrm{~B}$ & $1.06 \mathrm{~A}$ \\
\hline & \multicolumn{6}{|c|}{ Biodynamic Farming System } \\
\hline "Red Emmalie" & 97.92 FG & $71.45 \mathrm{EF}$ & $68.09 \mathrm{E}$ & $0.77 \mathrm{~F}$ & $0.70 \mathrm{C}$ & $1.88 \mathrm{~B}$ \\
\hline “Violetta" & $138.71 \mathrm{BC}$ & $94.44 \mathrm{CD}$ & $92.20 \mathrm{CD}$ & $0.74 \mathrm{~F}$ & $0.66 \mathrm{DE}$ & $0.84 \mathrm{DE}$ \\
\hline "Salad Blue" & 97.70 FG & $68.83 \mathrm{EF}$ & $66.91 \mathrm{E}$ & $0.64 \mathrm{~F}$ & $0.67 \mathrm{D}$ & $0.62 \mathrm{~F}$ \\
\hline “Tornado" & $185.74 \mathrm{~A}$ & $176.35 \mathrm{~A}$ & $173.16 \mathrm{~A}$ & $1.55 \mathrm{BC}$ & $0.95 \mathrm{~A}$ & $0.69 \mathrm{EF}$ \\
\hline “Laura” & 117.64 DE & $109.20 \mathrm{C}$ & $106.02 \mathrm{C}$ & $1.89 \mathrm{~A}$ & $0.68 \mathrm{CD}$ & $0.60 \mathrm{~F}$ \\
\hline Means & $127.54 \mathrm{~A}$ & $104.05 \mathrm{~A}$ & $101.28 \mathrm{~A}$ & $1.12 \mathrm{~A}$ & $0.73 \mathrm{~A}$ & $0.93 \mathrm{~A}$ \\
\hline
\end{tabular}

${ }^{1}$ Mean values in the same column marked by different capital letters differ statistically significantly $(p<0.05)$.

In the present study, among the tested potato cultivars, "Tornado" tubers with white flesh had the highest contents of phenolics (sum), phenolic acids (sum), and chlorogenic acid (Table 2).

Flavonoids form a widespread group of plant phenolic compounds responsible for the color of vegetables and fruits. We noticed that organically and biodynamically produced potatoes (except for "Salad Blue" cultivar) were significantly richer in flavonoids (sum), flavonols (sum), including quercetin-3-O-rutinoside and quercetin-3-O-glucoside, in comparison to the conventional ones (Table 3). Among the identified flavonols, quercetin-3-O-rutinoside was a predominant one in all potato cultivars. In agreement with our results, Kazimierczak et al. [18] reported significantly higher contents of flavonoids (sum), quercetin, and quercetin-3-O-rutinoside in organic tubers compared to the conventional ones. By contrast, Keutgen et al. [29] found higher contents of flavonoids in potato tubers when cultivated conventionally.

In the present study, the genotype significantly influenced the contents of flavonoids. Regarding the sum of flavonoids, the "Violetta" with dark purple flesh contained the highest contents (44.28 to $60.39 \mathrm{mg} 100 \mathrm{~g}^{-1} \mathrm{FM}$ ), while the significantly lowest contents were found in tubers of the "Laura"

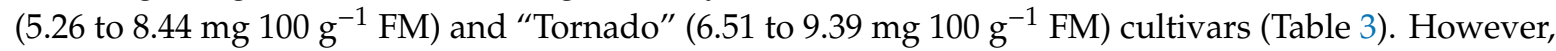
yellow-fleshed "Laura" and white-fleshed "Tornado" reached the highest concentrations of flavonols, such as quercetin and quercetin-3-O-rutinoside. As reported by Romero-Pérez et al. [30], flavonoids in plants are strongly impacted by genotype, the agroclimatic conditions, and the cultivation system. 
Table 3. The influence of the farming system on the content of flavonoids in the tubers of five potato cultivars.

\begin{tabular}{|c|c|c|c|c|c|}
\hline \multirow{2}{*}{ Potato Cultivars } & $\begin{array}{l}\text { Flavonoids } \\
\text { (sum) }\end{array}$ & $\begin{array}{l}\text { Flavonols } \\
\text { (sum) }\end{array}$ & Quercetin & $\begin{array}{l}\text { Quercetin-3-O- } \\
\text { Glucoside }\end{array}$ & $\begin{array}{l}\text { Quercetin-3-O- } \\
\text { Rutinoside }\end{array}$ \\
\hline & \multicolumn{5}{|c|}{ mg $100 \mathrm{~g}^{-1}$ Fresh Mass (FM) } \\
\hline & \multicolumn{5}{|c|}{ Conventional farming system } \\
\hline "Red Emmalie" & $18.28 \mathrm{G}^{1}$ & $3.14 \mathrm{~J}$ & $0.41 \mathrm{~A}$ & $0.66 \mathrm{DEF}$ & $2.07 \mathrm{H}$ \\
\hline “Violetta" & $49.70 \mathrm{~B}$ & $4.48 \mathrm{HI}$ & $0.21 \mathrm{E}$ & $0.69 \mathrm{DEF}$ & $3.58 \mathrm{EFG}$ \\
\hline "Salad Blue" & $35.50 \mathrm{D}$ & $3.50 \mathrm{IJ}$ & $0.21 \mathrm{E}$ & $0.32 \mathrm{HI}$ & $2.96 \mathrm{GH}$ \\
\hline “Tornado” & $6.51 \mathrm{~J}$ & $6.51 \mathrm{EF}$ & $0.37 \mathrm{~B}$ & $0.40 \mathrm{HI}$ & $5.74 \mathrm{CD}$ \\
\hline “Laura” & $5.26 \mathrm{~J}$ & $5.26 \mathrm{FGH}$ & $0.30 \mathrm{CD}$ & $0.43 \mathrm{GHI}$ & $4.53 \mathrm{EF}$ \\
\hline \multirow[t]{2}{*}{ Means } & $23.05 \mathrm{~A}$ & $4.58 \mathrm{~B}$ & $0.30 \mathrm{~A}$ & $0.50 \mathrm{~B}$ & $3.78 \mathrm{~B}$ \\
\hline & \multicolumn{5}{|c|}{ Organic farming system } \\
\hline "Red Emmalie" & $27.78 \mathrm{EF}$ & $5.97 \mathrm{EFG}$ & $0.39 \mathrm{~B}$ & $1.87 \mathrm{~B}$ & $3.81 \mathrm{EFG}$ \\
\hline “Violetta” & $60.39 \mathrm{~A}$ & $4.02 \mathrm{HIJ}$ & $0.21 \mathrm{E}$ & $0.31 \mathrm{I}$ & $3.50 \mathrm{FG}$ \\
\hline "Salad Blue" & $18.52 \mathrm{G}$ & $7.93 \mathrm{BCD}$ & $0.18 \mathrm{~F}$ & 0.48 FGHI & $7.27 \mathrm{AB}$ \\
\hline “Tornado" & $8.45 \mathrm{HI}$ & $8.05 \mathrm{BCD}$ & $0.37 \mathrm{~B}$ & $0.53 \mathrm{EFGH}$ & $7.14 \mathrm{AB}$ \\
\hline “Laura” & $8.11 \mathrm{HI}$ & $8.11 \mathrm{BCD}$ & $0.32 \mathrm{C}$ & $0.73 \mathrm{DE}$ & $7.06 \mathrm{AB}$ \\
\hline \multirow[t]{2}{*}{ Means } & $24.64 \mathrm{~A}$ & $6.90 \mathrm{~A}$ & $0.29 \mathrm{~A}$ & $0.78 \mathrm{~A}$ & $5.85 \mathrm{~A}$ \\
\hline & \multicolumn{5}{|c|}{ Biodynamic farming system } \\
\hline "Red Emmalie" & $26.47 \mathrm{~F}$ & $4.97 \mathrm{GH}$ & $0.30 \mathrm{CD}$ & $1.23 \mathrm{C}$ & $3.44 \mathrm{FG}$ \\
\hline “Violetta" & $44.28 \mathrm{C}$ & $7.13 \mathrm{CDE}$ & $0.18 \mathrm{~F}$ & $2.21 \mathrm{~A}$ & $4.74 \mathrm{DE}$ \\
\hline "Salad Blue" & $28.86 \mathrm{E}$ & $6.92 \mathrm{DE}$ & $0.32 \mathrm{C}$ & $0.62 \mathrm{EFG}$ & $5.98 \mathrm{BC}$ \\
\hline “Tornado" & $9.39 \mathrm{H}$ & $9.39 \mathrm{~A}$ & $0.42 \mathrm{~A}$ & $0.86 \mathrm{D}$ & $8.11 \mathrm{~A}$ \\
\hline “Laura” & $8.44 \mathrm{HI}$ & $8.44 \mathrm{AB}$ & $0.43 \mathrm{~A}$ & $0.67 \mathrm{DEF}$ & $7.34 \mathrm{~A}$ \\
\hline Means & $23.49 \mathrm{~A}$ & $7.37 \mathrm{~A}$ & $0.33 \mathrm{~A}$ & $1.12 \mathrm{~A}$ & $5.92 \mathrm{~A}$ \\
\hline
\end{tabular}

${ }^{1}$ Mean values in the same column marked by different capital letters differ statistically significantly $(p<0.05)$.

Our study has indicated that organic and biodynamic potato tubers contain higher concentrations of certain health-promoting phytochemicals than those produced under conventional farming standards. According to other authors, genotype (cultivar), climate conditions, and agronomical practices are the most important factors affecting the secondary metabolite composition of plants. To maximize the content of health-promoting compounds in the crop, it is crucial to select the appropriate cultivar and cultivation system [31,32].

Conventionally cultivated potatoes contained, on average, $18.47 \mathrm{mg} 100 \mathrm{~g}^{-1} \mathrm{FM}$ of anthocyanins (sum), while organic and biodynamic potatoes contained $17.67 \mathrm{mg} 100 \mathrm{~g}^{-1} \mathrm{FM}$ and $16.12 \mathrm{mg}$ $100 \mathrm{~g}^{-1} \mathrm{FM}$, respectively (Table 4). Organically and biodynamically grown "Red Emmalie" tubers and organically grown "Violetta" tubers accumulated higher contents of anthocyanins (sum) (19.77\%-30.58\%) and petunidin-3,5-di-O-glucoside (21.37\%-34.80\%) than conventionally grown tubers of the same cultivars. In the "Salad Blue" cultivar, the opposite situation was observed-conventional potatoes had significantly higher contents of anthocyanins (sum), petunidin-3,5-di-O-glucoside, peonidin-3,5-di-O-glucoside, and pelargonidin-3,5-di-O-glucoside. It could thus be concluded that the genotypic variety of colored-flesh potatoes had a greater impact on the content of individual anthocyanins than the agricultural production system [1].

To the best of our knowledge, there is no other published research on the effects of farming practices on the anthocyanins content in colored potatoes. However, a higher content of anthocyanins in biodynamic (but not organic) versus conventional lettuce was reported by Heimler et al. [33]. Another study has shown that biodynamic strawberries had a significantly higher content of cyanidin-3-glucoside and pelargonidin-3-glucoside compared to conventional fruits [34]. Spanish researchers compared the contents of anthocyanins in red grapes cultivated in conventional and organic systems; however, they did not identify any major differences [35]. 
Table 4. The influence of the farming system on the content of anthocyanins in the tubers of five potato cultivars.

\begin{tabular}{|c|c|c|c|c|}
\hline \multirow[t]{2}{*}{ Potato Cultivars } & $\begin{array}{l}\text { Anthocyanins } \\
\text { (sum) }\end{array}$ & $\begin{array}{l}\text { Petunidin-3,5-di-O- } \\
\text { Glucoside }\end{array}$ & $\begin{array}{l}\text { Pelargonidin-3,5-di-O- } \\
\text { Glucoside }\end{array}$ & $\begin{array}{l}\text { Peonidin-3,5-di- } O \\
\text { Glucoside }\end{array}$ \\
\hline & \multicolumn{4}{|c|}{ mg $100 \mathrm{~g}^{-1}$ Fresh Mass (FM) } \\
\hline & \multicolumn{4}{|c|}{ Conventional farming system } \\
\hline "Red Emmalie" & $15.14 \mathrm{~F}^{1}$ & $12.44 \mathrm{~F}$ & $1.30 \mathrm{D}$ & $1.41 \mathrm{D}$ \\
\hline “Violetta" & $45.23 \mathrm{~B}$ & $42.12 \mathrm{~B}$ & $1.48 \mathrm{~A}$ & $1.63 \mathrm{~A}$ \\
\hline "Salad Blue" & $31.99 \mathrm{D}$ & $28.97 \mathrm{D}$ & $1.43 \mathrm{~B}$ & $1.60 \mathrm{~B}$ \\
\hline “Tornado” & $0.00 \mathrm{H}$ & $0.00 \mathrm{H}$ & $0.00 \mathrm{~F}$ & $0.00 \mathrm{~F}$ \\
\hline "Laura" & $0.00 \mathrm{H}$ & $0.00 \mathrm{H}$ & $0.00 \mathrm{~F}$ & $0.00 \mathrm{~F}$ \\
\hline \multirow[t]{2}{*}{ Means } & $18.47 \mathrm{~A}$ & $16.71 \mathrm{~A}$ & $0.84 \mathrm{~A}$ & $0.93 \mathrm{~A}$ \\
\hline & \multicolumn{4}{|c|}{ Organic farming system } \\
\hline "Red Emmalie" & $21.81 \mathrm{E}$ & $19.08 \mathrm{E}$ & $1.31 \mathrm{D}$ & $1.42 \mathrm{D}$ \\
\hline "Violetta" & $56.38 \mathrm{~A}$ & $53.57 \mathrm{~A}$ & $1.37 \mathrm{C}$ & $1.43 \mathrm{D}$ \\
\hline "Salad Blue" & $10.16 \mathrm{G}$ & $7.41 \mathrm{G}$ & $1.32 \mathrm{D}$ & $1.42 \mathrm{D}$ \\
\hline “Tornado" & $0.00 \mathrm{H}$ & $0.00 \mathrm{H}$ & $0.00 \mathrm{~F}$ & $0.00 \mathrm{~F}$ \\
\hline "Laura" & $0.00 \mathrm{H}$ & $0.00 \mathrm{H}$ & $0.00 \mathrm{~F}$ & $0.00 \mathrm{~F}$ \\
\hline \multirow[t]{2}{*}{ Means } & 17.67A & $16.01 \mathrm{~A}$ & $0.80 \mathrm{~A}$ & $0.85 \mathrm{~A}$ \\
\hline & \multicolumn{4}{|c|}{ Biodynamic farming system } \\
\hline "Red Emmalie" & $21.50 \mathrm{E}$ & $18.89 \mathrm{E}$ & $1.25 \mathrm{E}$ & $1.36 \mathrm{E}$ \\
\hline "Violetta" & $37.15 \mathrm{C}$ & $34.35 \mathrm{C}$ & $1.31 \mathrm{D}$ & $1.48 \mathrm{C}$ \\
\hline "Salad Blue" & $21.94 \mathrm{E}$ & $19.28 \mathrm{E}$ & $1.26 \mathrm{E}$ & $1.40 \mathrm{D}$ \\
\hline “Tornado" & $0.00 \mathrm{H}$ & $0.00 \mathrm{H}$ & $0.00 \mathrm{~F}$ & $0.00 \mathrm{~F}$ \\
\hline “Laura” & $0.00 \mathrm{H}$ & $0.00 \mathrm{H}$ & $0.00 \mathrm{~F}$ & $0.00 \mathrm{~F}$ \\
\hline Means & $16.12 \mathrm{~A}$ & $15.04 \mathrm{~A}$ & $0.76 \mathrm{~A}$ & $0.85 \mathrm{~A}$ \\
\hline
\end{tabular}

${ }^{1}$ Mean values in the same column marked by different capital letters differ statistically significantly $(p<0.05)$.

As already indicated, our data indicate that the genotypic variety of potatoes played an important role in distinguishing potato samples according to the content of anthocyanins. The "Violetta" cultivar with dark purple flesh and skin contained a significantly higher content (in all farming systems) of

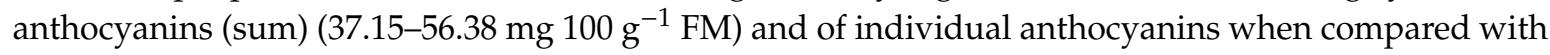
the other tested potato cultivars (Table 4). A lower content of this pigment was found in the light purple-fleshed "Salad Blue" (10.16-31.99 mg $\left.100 \mathrm{~g}^{-1} \mathrm{FM}\right)$ and red "Red Emmalie" (15.14-21.81 mg $\left.100 \mathrm{~g}^{-1} \mathrm{FM}\right)$. The contents of anthocyanins in our study were in the range reported in the scientific literature for colored potato cultivars [36]. The main anthocyanin in all cultivars was petunidin (72.93\%-95.02\%). Furthermore, pelargonidin and peonidin were identified in all the analyzed purple and red potato samples. However, anthocyanins were not detected in tubers of white and yellow color. Our data are in agreement with results by Tierno et al. [37] and Andre et al. [38]. In these studies, anthocyanins were not detected in potato tubers with yellow and white flesh. These compounds were identified only in the tubers with red- and purple-colored flesh and/or skin.

\subsection{Carotenoids Content}

According to the literature, the total and individual carotenoid content in the potato tubers is associated with their color and is positively correlated with yellow color intensity [39].

Our data showed that the content of carotenoids in the tubers was impacted by the growing system and potato genotype. The highest contents of carotenoids (sum), lutein, and $\beta$-carotene were found in

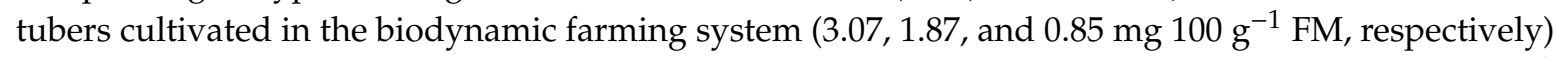
and the lowest contents were found in the conventional farming system $\left(1.71,0.85\right.$, and $0.51 \mathrm{mg} 100 \mathrm{~g}^{-1}$ FM, respectively) (Table 5). Other authors' studies on the concentrations of carotenoids in organic 
food resulted in conflicting outcomes, showing, e.g., higher contents of these compounds in organic tomatoes [40,41], but lower contents in organic sweet pepper fruits [42,43] when compared with the fruit produced with the conventional methods. In a study on potatoes, Tatarowska et al. [44] found that the accumulation of carotenoids was higher in organically compared to the conventionally grown tubers. These authors reported that organic farming conditions could activate carotenogenesis in potato tubers. According to Rockholm and Yamamoto [45], organic matter could also increase the acidity of the soil, which would impact the epoxidation and de-epoxidation reactions of carotenoid in the xanthophyll cycle. However, Kotikova et al. [46] have obtained the results showing no significant effects of the fertilization on the carotenoids content in potatoes.

Table 5. The influence of the farming system on the content of carotenoids in "Laura" tubers.

\begin{tabular}{|c|c|c|c|c|}
\hline \multirow{2}{*}{ Farming System } & Carotenoids (sum) & Lutein & Zeaxanthin & $\beta$-Carotene \\
\hline & \multicolumn{4}{|c|}{ mg $100 \mathrm{~g}^{-1}$ Fresh Mass (FM) } \\
\hline Conventional & $1.71 \mathrm{C}^{1}$ & $0.85 \mathrm{C}$ & $0.35 \mathrm{~A}$ & $0.51 \mathrm{C}$ \\
\hline Organic & $2.50 \mathrm{~B}$ & $1.36 \mathrm{~B}$ & $0.33 \mathrm{~B}$ & $0.80 \mathrm{~B}$ \\
\hline Biodynamic & $3.07 \mathrm{~A}$ & $1.87 \mathrm{~A}$ & $0.35 \mathrm{~A}$ & $0.85 \mathrm{~A}$ \\
\hline
\end{tabular}

${ }^{1}$ Mean values in the same column marked by different capital letters differ statistically significantly $(p<0.05)$.

Carotenoids were only identified in "Laura" with yellow flesh (Table 5). Only traces of these pigments were detected in other tested potato cultivars. The main identified carotenoid was lutein $(49.71 \%-60.91 \%)$. Furthermore, zeaxanthin $(11.40 \%-20.46 \%)$ and $\beta$-carotene $(27.69 \%-32.00 \%)$ were identified in "Laura" tubers. In contrast to our results, other studies have reported minor contents of carotenoids in red and purple potato tubers. Kotíková et al. [47] found that the average carotenoid content in yellow cultivars was $2.62 \mathrm{mg} 100 \mathrm{~g} \mathrm{~g}^{-1} \mathrm{DW}$, while, in purple-fleshed potatoes, it was $0.57 \mathrm{mg}$ $100 \mathrm{~g}^{-1}$ DW. Hamouz et al. [48] reported that the total carotenoid content of red/purple-fleshed cultivars


The different carotenoid extraction and analytical methods could be the causes of differences in these investigations. Moreover, as already discussed, the pigment content in potato tubers depends on many factors such as location, genotype, climate, and growing conditions.

\subsection{Principal Component Analysis}

Principal component analysis (PCA) was used to explore the variation and identify potential patterns within the dataset and to look into the relationships between the concentrations of bioactive compounds in potato samples. The PCA biplot graphically summarized the distribution of data for the 19 bioactive compounds presented in Tables $2-5$

The result of principal component analysis indicated two principal components (PC1 and PC2), representing most of the information on the measured antioxidants, which explain $70.87 \%$ of the total variance (Figure 1). The first axis (PC1) represents $52.98 \%$ of the total variance. The second axis (PC2) represents $17.89 \%$ of the total variance.

As shown in Figure 1, the potato samples were divided into three groups on the principal component analysis map. The L-C, L-O, and L-B were associated with higher concentrations of gallic acid, quercetin, carotenoids (sum), and individual carotenoids (lutein, zeaxanthin, and $\beta$-carotene). $\mathrm{T}-\mathrm{B}, \mathrm{T}-\mathrm{C}$, and T-O formed other groups. This was formed due to the higher contents of phenolics (sum), phenolic acids (sum), as well as chlorogenic, caffeic, and p-coumaric acids. SB-O, V-B, SB-B, RE-O, RE-B, RE-C, V-O, V-C, and SB-C were grouped closely due to possessing higher contents of flavonoids (sum), anthocyanins (sum) and individual anthocyanins such as pelargonidin-3,5-di-O-glucoside, petunidin-3,5-di-O-glucoside, and peonidin-3,5-di-O-glucoside. 




Figure 1. Principal component analysis of bioactive substances concentrations in potato tubers (sum of polyphenols (TP), sum of phenolic acids (TPA), gallic acid (GA), chlorogenic acid (ChA), caffeic acid (CA), p-coumaric acid (P-CouA), sum of flavonoids (TFd), sum of flavonols (TFl), quercetin-3-O-rutinoside (Q-3-O-R), quercetin (Que), quercetin-3-O-glucoside (Q-3-O-G), sum of anthocyanins (TA), petunidin-3,5-di-O-glucoside (Pet-G), pelargonidin-3,5-di-O-glucoside (Pel-G), peonidin-3,5-di-O-glucoside (Peo-G), sum of carotenoids (TC), lutein (Lut), zeaxanthin (Zea), and $\beta$-carotene (b-Car), "Red Emmalie"-conventional (RE-C), "Violetta"-conventional (V-C), "Salad Blue"-conventional (SB-C), "Laura"-conventional (L-C), “Tornado"-conventional (T-C), “Red Emmalie"-organic (RE-O), “Violetta"-organic (V-O), “Salad Blue”-organic (SB-O), “Laura"-organic (L-O), “Tornado"-organic (T-O), “Red Emmalie"-biodynamic (RE-B), “Violetta”-biodynamic (V-B), "Salad Blue"-biodynamic (SB-B), “Laura"-biodynamic (L-B), and “Tornado"-biodynamic (T-B)).

\section{Conclusions}

This study demonstrates variation in the content of polyphenols and carotenoids between potato cultivars grown in conventional, organic, and biodynamic farming systems. Higher contents of polyphenols (sum), phenolic acids (sum), chlorogenic acid, p-coumaric acid, caffeic acid, carotenoids (sum), lutein, and $\beta$-carotene were determined in the biodynamic potato tubers compared to the conventional ones. However, the content of these compounds showed no significant difference among the conventional and organic samples. Moreover, organically and biodynamically cultivated potatoes (except the "Salad Blue" cultivar) were essentially richer in flavonoids and anthocyanins. When comparing the cultivars, higher contents of polyphenols (sum), phenolic acids (sum), chlorogenic acid, and p-coumaric acid were found in "Tornado" tubers. "Violetta" contained significantly more of flavonoids (sum), anthocyanins (sum), and individual compounds, such as petunidin-3,5-di-O-glucoside, pelargonidin-3,5-di-O-glucoside, and peonidin-3,5-di-O-glucoside. Carotenoids were only found in "Laura" tubers with yellow flesh. Principal component analysis and hierarchical cluster analysis were used to characterize differences in bioactive compounds between potato cultivars grown in biodynamic, organic, and conventional systems. Besides farming practices, clear clustering related to the effects of the genotype (cultivars) was shown.

In conclusion, the study showed a richer biochemical composition of biodynamic and organic samples compared to the conventional ones in the case of some of the tested cultivars. It is crucial to match the best agronomic methods and cultivars to maximize the contents of bioactive compounds with health-promoting properties. However, further studies are needed to explain the processes connected with the influence of farming methods on potato quality (especially on potato cultivars with colored flesh). 
Supplementary Materials: The following are available online at http://www.mdpi.com/2071-1050/12/7/2701/s1, Figure S1. Standard curves with individual LOD for all bioactive compounds identified in experiment in potato tubers, Figure S2. Standard curves with individual LOD for all bioactive compounds identified in experiment in potato tubers, Figure S3. Chromatograms of polyphenols in examined potato cultivars from conventional production: [A] Red Emmalie; [B] Violetta; [C] Salad Blue; [D] Tornado; [E] Laura. (1) gallic acid; (2) chlorogenic acid; (3) caffeic acid; (4) quercetin-3-O-rutinoside; (5) p-coumaric acid; (6) quercetin; (7) quercetin-3-O-glucodise; (8) petunidin-3,5-di-O-glucoside; (9) pelargonidin-3,5-di-O-glucoside; (10) peonidin-3,5-di-O-glucoside. Figure S4. Chromatograms of polyphenols in examined potato cultivars from organic production: [A] Red Emmalie; [B] Violetta; [C] Salad Blue; [D] Tornado; [E] Laura. (1) gallic acid; (2) chlorogenic acid; (3) caffeic acid; (4) quercetin-3-O-rutinoside; (5) p-coumaric acid; (6) quercetin; (7) quercetin-3-O-glucodise; (8) petunidin-3,5-di-O-glucoside; (9) pelargonidin-3,5-di-O-glucoside; (10) peonidin-3,5-di-O-glucoside. Figure S5. Chromatograms of polyphenols in examined potato cultivars from biodynamic production: [A] Red Emmalie; [B] Violetta; [C] Salad Blue; [D] Tornado; [E] Laura. (1) gallic acid; (2) chlorogenic acid; (3) caffeic acid; (4) quercetin-3-O-rutinoside; (5) p-coumaric acid; (6) quercetin; (7) quercetin-3-O-glucodise; (8) petunidin-3,5-di-O-glucoside; (9) pelargonidin-3,5-di-O-glucoside; (10) peonidin-3,5-di-O-glucoside.

Author Contributions: Conceptualization, E.J., N.V., J.K., H.D., D.Ś.-T, and E.R.; methodology, E.J., N.V., J.K., H.D., and E.H.; funding acquisition E.J. and D.Ś.-T.; software, N.V.; investigation, E.H.; writing-original draft preparation, N.V., J.K., and D.L.; writing—review and editing, E.J., N.V., J.K., D.L., E.H., and D.Ś.-T; supervision, E.J.; project administration, J.K. All authors have read and agreed to the published version of the manuscript.

Funding: This research was funded by the Ekhagastiftelsen Foundation (Sweden), within the project "Effect of farming systems on the accumulation of biologically active and anticancer compounds of potato tubers with coloured flesh" (No. 2017-33).

Conflicts of Interest: The authors declare no conflict of interest.

\section{References}

1. Lachman, J.; Hamouz, K.; Šulc, M.; Orsák, M.; Pivec, V.; Hejtmánková, A.; Dvořák, P.; Čepl, J. Cultivar differences of total anthocyanins and anthocyanidins in red and purple-fleshed potatoes and their relation to antioxidant activity. Food Chem. 2009, 114, 836-843. [CrossRef]

2. Srivastava, A.; Kumar, S. Study of biochemical changes in Solanum tuberosum due to infection and storage. J. Chem. Pharm. Res. 2012, 4, 2733-2739.

3. Jansen, G.; Flamme, W. Coloured potatoes (Solanum tuberosum L.) - Anthocyanin content and tuber quality. Genet. Resour. Crop Evol. 2006, 53, 1321-1331. [CrossRef]

4. Vaitkevičienè, N.; Jarienè, E.; Ingold, R.; Peschke, J. Effect of biodynamic preparations on the soil biological and agrochemical properties and coloured potato tubers quality. Open Agric. 2019, 4, 17-23. [CrossRef]

5. Reddivari, L.; Vanamala, J.; Chintharlapalli, S.; Safe, S.H.; Miller, J. Anthocyanin fraction from potato extracts is cytotoxic to prostate cancer cells through activation of caspase-dependent and caspase-independent pathways. Carcinogenesis 2007, 28, 2227-2235. [CrossRef]

6. Thompson, M.D.; Thompson, H.J.; McGinley, J.N.; Neil, E.S.; Rush, D.K.; Holm, D.G. Functional food characteristics of potato cultivars (Solanum tuberosum L.): Photochemical composition and inhibition of 1-methyl-1-nitrosourea induced breast cancer in rats. J. Food Compos. Anal. 2009, 22, 571-576. [CrossRef]

7. Nichenametla, S.N.; Taruscio, T.G.; Barney, D.L.; Exon, J.H.A. Review of the effects and mechanisms of polyphenolics in cancer. Crit. Rev. Food Sci. Nutr. 2006, 46, 161-183. [CrossRef]

8. Shih, P.H.; Yeh, C.T.; Yen, G.C. Effects of anthocyanin on the inhibition of proliferation and induction of apoptosis in human gastric adenocarcinoma cells. Food Chem. Toxicol. 2005, 43, 1557-1566. [CrossRef]

9. Stoner, G.D.; Chen, T.; Kresty, L.A.; Aziz, R.M.; Reinemann, T.; Nines, R. Protection against esophageal cancer in rodents with lyophilized berries: Potential mechanisms. Nutr. Cancer. 2006, 54, 33-46. [CrossRef]

10. Ponzio, C.; Gangatharan, R.; Neri, D. Organic and biodynamic agriculture: A review in relation to sustainability. Int. J. Plant Soil Sci. 2013, 2, 95-110. [CrossRef]

11. Carpenter-Boggs, L.; Kennedy, A.C.; Reganold, J.P. Organic and biodynamic management: Effects on soil biology. Soil Sci. Soc. Am. J. 2000, 64, 1651-1659. [CrossRef]

12. Koepf, H.H. Research in Biodynamic Agriculture: Methods and Results; Bio-Dynamic Farming and Gardening Association Inc.: Kimberton, Pennsylvania, 1993.

13. Köpke, U. Organic foods: Do they have a role. In Diet Diversification and Health Promotion; Elmadfa, I., Ed.; Karger: Basel, Switzerland, 2005; Volume 57, pp. 62-72. 
14. Ngadze, E.; Coutinho, T.; Icishahayo, D.; van der Waals, J. Effect of calcium soil amendments on phenolic compounds and soft rot resistance in potato tubers. Crop Prot. 2014, 62, 40-45. [CrossRef]

15. Stratil, P.; Klejdus, B.; Kubáň, V. Determination of total content of phenolic compounds and their antioxidant activity in vegetables evaluation of spectrophotometric methods. J. Agric. Food Chem. 2006, 54, 607-616. [CrossRef]

16. Burmeister, A.; Bondiek, S.; Apel, L.; Kühne, C.; Hillebrand, S.; Fleischmann, P. Comparison of carotenoid and anthocyanin profiles of raw and boiled solanum tuberosum and solanum phureja tubers. J. Food Comp Anal. 2011, 24, 865-872. [CrossRef]

17. Rodriguez-Saona, L.E.; Giusti, M.M.; Wrolstad, R.E. Anthocyanin pigment composition of red-fleshed potatoes. J. Food. Sci. 1998, 63, 458-465. [CrossRef]

18. Kazimierczak, R.; Srednicka-Tober, D.; Hallmann, E.; Kopczynska, K.; Zarzynska, K. The impact of organic vs. conventional agricultural practices on selected quality features of eight potato cultivars. Agronomy 2019, 9, 799. [CrossRef]

19. Barański, M.; Srednicka-Tober, D.; Volakakis, N.; Seal, C.; Sanderson, R.; Stewart, G.B.; Benbrook, C.; Biavati, B.; Markellou, E.; Giotis, C.; et al. Higher antioxidant and lower cadmium concentrations and lower incidence of pesticide residues in organically grown crops: A systematic literature review and meta-analyses. Br. J. Nutr. 2014, 112, 794-811. [CrossRef]

20. Brand, K.; Leifert, C.; Sanderson, R.; Seal, C.J. Agroecosystem management and nutritional quality of plant foods: The case of organic fruits and vegetables. Crit. Rev. Plant Sci. 2011, 30, 177-197. [CrossRef]

21. Fritz, J.; Kopke, U.; Alfoldi, T.; Lockeretz, W.; Niggli, U. Horn silica appli-cation in combination with plant extracts. In Proceedings of the 13th International IFOAM Scientific Conference, Basel, Switzerland, 25 August-2 September 2000; p. 416.

22. Jayasree, P.; George, A. Do biodynamic practices influence yield, quality and economics of cultivation of chilli (Capsicum annuum L.). Int. J. Trop. Agric. 2006, 44, 68-70.

23. Jarienè, E.; Vaitkevičienė, N.; Danilčenko, H.; Tajner-Czopek, A.; Rytel, E.; Kucharska, A.; Sokół-Łętowska, A.; Gertchen, M.; Jeznach, M. Effect of biodynamic preparations on the phenolic antioxidants in potatoes with colouredflesh. Biol. Agric. Hortic. 2017, 33, 172-182. [CrossRef]

24. Hallmann, E. The influence of organic and conventional cultivation systems on the nutritional value and content of bioactive compounds in selected tomato types. J. Sci. Food Agric. 2012, 92, 2840-2848. [CrossRef]

25. Veberic, R. The impact of production technology on plant phenolics. Horticulturae 2016, 2, 8. [CrossRef]

26. Akula, R.; Ravishankar, G.A. Influence of abiotic stress signals on secondary metabolites in plants. Plant Signal. Behav. 2011, 6, 1720-1731. [CrossRef]

27. Jeon, T.W.; Cho, Y.S.; Lee, S.H.; Cho, S.M.; Cho, H.M.; Chang, K.S.; Park, H.J. Studies on the biological activities and physicochemical characteristics of pigments extracted from Korean purple-fleshed potato. Korean J. Food Sci. Technol. 2005, 37, 247-254.

28. Brazinskiene, V.; Asakaviciute, R.; Miezeliene, A.; Alencikiene, G.; Ivanauskas, L.; Jakstas, V.; Viskelis, P.; Razukas, A. Effect of farming systems on the yield, quality parameters and sensory properties of conventionally and organically grown potato (Solanum tuberosum L.) tubers. Food Chem. 2014, 145, 903-909. [CrossRef]

29. Keutgen, A.J.; Wszelaczyńska, E.; Pobereżny, J.; Przewodowska, A.; Przewodowski, W.; Milczarek, D.; Tatarowska, B.; Flis, B.; Keutgen, N. Antioxidant properties of potato tubers (Solanum tuberosum L.) as a consequence of genetic potential and growing conditions. PLoS ONE 2019, 14, e222976. [CrossRef]

30. Romero-Pérez, A.I.; Lamuela-Raventós, R.M.; Andrés-Lacueva, C.; De La Carmen Torre-Boronat, M. Method for the quantitative extraction of resveratrol and piceid isomers in grape berry skins. Efect of powdery mildew on the stilbene content. J. Agric. Food Chem. 2001, 49, 210-215. [CrossRef]

31. Oh, M.-M.; Carey, E.E.; Rajashekar, C.B. Environmental stresses induce health-promoting phytochemicals in lettuce. Plant Physiol. Biochem. 2009, 47, 578-583. [CrossRef]

32. Lv, J.; Lu, Y.; Niu, Y.; Whent, M.; Ramadan, M.F.; Costa, J.; Yu, L.L. Effect of genotype, environment, and their interaction on phytochemical compositions and antioxidant properties of soft winter wheat flour. Food Chem. 2013, 138, 454-462. [CrossRef]

33. Heimler, D.; Vignolini, P.; Arfaioli, P.; Isolani, L.; Romani, A. Conventional, organic and biodynamic farming: Differences in polyphenol content and antioxidant activity of Batavia lettuce. J. Sci. Food Agric. 2012, 92, 551-556. [CrossRef] 
34. D’Evoli, L.; Tarozzi, A.; Hrelia, P.; Lucarini, M.; Gabrielli, F.; Franco, F.; Morroni, F.; Cantelli-Forti, G.; Lombardi-Boccia, G. Influence of cultivation system on bioactive molecule synthesis in strawberries: Spin-off on antioxidant and antiproliferative activity. J. Food Sci. 2010, 75, 94-99. [CrossRef] [PubMed]

35. Mulero, J.; Pardo, F.; Zafrilla, P. Antioxidant activity and phenolic compounds in conventional and organic red grapes (var Monastrell). CyTA J. Food 2010, 8, 185-191. [CrossRef]

36. Hamouz, K.; Lachman, J.; Pazderů, K.; Tomášek, J.; Hejtmánková, H.; Pivec, V. Differences in anthocyanin content and antioxidant activity of potato tubers with different flesh colour. Plant Soil Environ. 2011, 57, 478-485. [CrossRef]

37. Tierno, R.; Hornero-Méndez, D.; Gallardo-Guerrero, L.; López Pardo, R.; Ruiz de Galarreta, J.I. Effect of boiling on the total phenolic, anthocyanin and carotenoid concentrations of potato tubers from selected cultivars and introgressed breeding lines from native potato species. J. Food Compos Anal. 2015, 41, 58-65. [CrossRef]

38. Andre, C.M.; Oufir, M.; Guignard, C.; Hoffmann, L.; Hausman, J.F.; Evers, D.; Larondelle, Y. Antioxidant profiling of native Andean potato tubers (Solanum tuberosum L.) reveals cultivars with high levels of $\beta$-carotene, $\alpha$-tocopherol, chlorogenic acid and petanin. J. Agric. Food Chem. 2007, 55, 10839-10849. [CrossRef]

39. Hejtmánková, K.; Kotíková, Z.; Hamouz, K.; Pivec, V.; Vacek, J.; Lachman, J. Influence of flesh colour, year and growing area on carotenoid and anthocyanin content in potato tubers. J. Food Compos Anal. 2013, 32, 20-27. [CrossRef]

40. Caris-Veyrat, C.; Amiot, M.J.; Tyssandier, V.; Grasselly, D.; Buret, M.; Mikolajczak, M.; Guilland, J.C.; Bouteloup-Demange, C.; Borel, P. Influence of organic versus conventional agricultural practice on the antioxidant microconstituent content of tomatoes and derived purees; consequences on antioxidant plasma status in humans. J. Agric. Food Chem. 2004, 52, 6503-6509. [CrossRef]

41. Kapoulas, N.; Ilić, Z.S.; Đurovka, M.; Trajković, R.; Milenković, L. Effect of organic and conventional production practices on nutritional value and antioxidant activity of tomatoes. African J. Biotechnol. 2011, 10, 15938-15945. [CrossRef]

42. Rembiałkowska, E.; Hallmann, E. The changes of the bioactive compounds in pickled red pepper fruits from organic and conventional production. J. Res. Applic. Agric. Engin. 2008, 53, 51-57.

43. Deepa, N.; Kaur, C.; George, B.; Singh, B.; Kapoor, H.C. Antioxidant constituents in some sweet pepper (Capsicum annuum L.) genotypes during maturity. LWT-Food Sci. Technol. 2007, 40, 121-129. [CrossRef]

44. Tatarowska, B.; Milczarek, D.; Jakuczun, H.; Stochmal, A.; Pecio, Ł.; Flis, B. The potential for the improvement of carotenoids level in potato-Effect of the genotype and environment. J. Food Agric. Environ. 2014, 12, 536-540.

45. Rockholm, D.C.; Yamamoto, H.Y. Violaxanthin De-Epoxidase. Purification of a 43-kilodalton lumenal protein from lettuce by lipid-affinity precipitation with monogalactosyldiacylglyceride. J. Plant Physiol. 1996, 110, 697-703. [CrossRef] [PubMed]

46. Kotikova, Z.; Hejtmankova, A.; Lachman, J.; Hamouz, K.; Trnkova, E.; Dvorak, P. Effect of selected factors on total carotenoid content in potato tubers (Solanum tuberosum L.). Plant Soil Environ. 2007, 53, 355-360. [CrossRef]

47. Kotíková, Z.; Šulc, M.; Lachman, J.; Pivec, V.; Orsák, M.; Hamouz, K. Carotenoid profile and retention in yellow-, purple- and red-fleshed potatoes after thermal processing. Food Chem. 2016, 15, 992-1001. [CrossRef] [PubMed]

48. Hamouz, K.; Pazderu, K.; Lachman, J.; Čepl, J.; Kotíková, Z. Effect of cultivar, flesh colour, locality and year on carotenoid content in potato tubers. Plant Soil Environ. 2016, 62, 86-91. [CrossRef]

(C) 2020 by the authors. Licensee MDPI, Basel, Switzerland. This article is an open access article distributed under the terms and conditions of the Creative Commons Attribution (CC BY) license (http://creativecommons.org/licenses/by/4.0/). 